\title{
()
}

\section{Fantasy of Conviviality: Banalities of Multicultural Settings and What We Do (Not) Notice When We Look at Them}

\author{
Magdalena Nowicka
}

\section{INTRODUCTION}

Since my first engagement with conviviality in 2011 when preparing the conference I co-organised in Göttingen with Steven Vertovec, Peter van der Veer and Arjun Appadurai, and the year following the conference which I dedicated to the edited volume on comparing convivialities (Nowicka and Vertovec 2014), the term conviviality has gained popularity I/we did not envision. My own motivation for the conference back in 2011/2012 was to move the discussion on diversity beyond cosmopolitanism. At that time, I considered the concept of cosmopolitanism to be too Eurocentric and too normative, as well as too overstrained in the scholarly and public debates to be analytically useful, and I saw two alternatives: to reject it or to radically change it (Braidotti 2013). I thus probed conviviality as a way of reflecting on the shortages of cosmopolitanism and more broadly on how

\footnotetext{
M. Nowicka $(\varangle)$

DeZIM e.V and Humboldt-Universität zu Berlin, Berlin, Germany

e-mail: nowicka@dezim-institut.de

(C) The Author(s) 2020

O. Hemer et al. (eds.), Conviviality at the Crossroads, https://doi.org/10.1007/978-3-030-28979-9_2
} 
other authors approach the issue of 'living-with-difference'. In particular, it made me re-think 'difference' (Lisiak and Nowicka 2017).

I now look back at the last years of the scholarly debate which followed the proposal (I do not intend to claim that it was earned to our publication) to think of human diversity and inter-personal relations with the help of the notion of 'conviviality'. This review is not only positive: I see a tendency to map places, people and situations as convivial, in opposition to places, people and situations which are less so. I had criticised this kind of tedious exercise in relation to cosmopolitanism, and this critique was one of the reasons I engaged with conviviality. Further, I notice that conviviality becomes particularly popular in the context of studies in settings which are shaped by international migration. While this was also a focus on our first contribution on conviviality (Nowicka and Vertovec 2014), owing to the empirical work we have been doing, I feel this does not meet the expectations I had for this term. I saw its potential rather in how conviviality could help us to reframe the debates on society, not on diversity, as I elaborate in this chapter.

In this chapter I use the term 'fantasy', for it points towards something imaginary, desired but chimerical. In the current and past debates, conviviality emerges as an imaginary of the relationship between me/us and them/others (Gilroy 2004). Alike cosmopolitanism it engages ideas around identity and difference (Moore 2013). The majority of works on conviviality dedicates attention to the myriad of fleeting intersections and interactions between people, leaving the issue of state policies for managing 'diversity' unaddressed. The main challenge for social sciences, it seems, is the chimerical nature of mundane human encounters. On the other hand, many engagements with conviviality convey a fantasy in terms of a desired condition. Thereby, the works which focus the 'factual' are as normative as these works which convey a vision of convivial (future) society, for 'facts' only make sense in a particular normative order (Taylor 2004). Throughout this chapter, thus, I will try to show how the scholarly notion of conviviality is embedded in the Western normative order which relies on the imaginary of an individual as a social being. The potential I see in employing the notion of conviviality relates to a shift in focus on individual towards the sociality. I realise this is not a new postulate (we may think, e.g., of social studies of science and technology which urged us to re-think the notion of individual subject and agency), but I think we have arrived at the point when we could consider the very premise of our scholarly engagement with 'the social' anew. 
In order to do so, I engage closer with conviviality as a mode of thinking of human togetherness. My reflections are based on the reading of two books which introduce a historical perspective on norms and ideas around 'con-vivir' - 'living together': Charles Taylor's Modern Social Imaginaries (2004) and Almudena Hernando's The Fantasy of Individuality (2017). These works serve me as heuristics to make sense of the conviviality debate and to identify its potentials and pitfalls. I do not intend here a comprehensive theory of conviviality through an intense engagement with philosophy or social theory. My ambition is rather small: I look at the field which I know best, which is migration and diversity studies, and develop a proposal for its conceptual renewal along the lines of conviviality. The main question which I follow is how the myth of individuality shapes research in this field and how this research could be different.

I start the contribution with a short summary of the key arguments of Taylor (2004) and Hernando (2017). Out of many possible aspects these authors discuss I selected three which serve me as a lens to look at the conviviality literature: (1) courtesy and civility; (2) collaboration and alliances; and (3) social individuals. As the reader will notice, these aspects are intertwined: courtesy and civility entail collaboration and alliances, and these are possible thanks to and contribute to the sense of an individual as a social being. By analytically distinguishing these aspects I want to emphasise the imaginaries with which the authors writing about conviviality operate. Thereby, my review moves swiftly between the micro- and macro-level of sociality. This is intentional here, but not common in the literature on conviviality which either focuses global challenges or local, ordinary practices. In my review, I am inclined to accept Bourdieu's standpoint that micropractices are significant for reproduction of macrostructures of societies.

I contrast these practices, ideas and places which are made visible by the literature on conviviality, with what this literature omits when discussing conviviality - family, friendship, relations of care and intimacy, private sphere, power and identity and gender relations. I argue these omissions are to be understood in the context of Western modern social imaginary. This embedding of conviviality in Western modern social imaginary hinders us from developing the full potential of the term 'conviviality'. Thus, I ask how could it be otherwise? What would it mean to reject this heritage and move the discussion beyond it? 


\section{(Western Modern) Social IMAginary}

The Canadian philosopher Charles Taylor proposed the concept social imaginary to describe what he considers builds up the core of Western modernity. Social imaginary according to Taylor means ideas, convictions, ideals, understandings, norms and values surrounding living together as humans (Taylor 2004). Social imaginary is both factual and normative because the idea of how things should go, and how things usually go, is interwoven: what and how we do things make sense only within this specific social imaginary, even if we are not necessarily able to explain our behaviour. Social imaginary is thus a largely inarticulate understanding, but some parts of it can be explicated as doctrines or theories of our social world and perpetuated and changed by them. Taylor analyses several elements of what he calls Western modern social imaginary. At the core of it, Taylor argues, is the idea of society of autonomous individuals who come together to form a political entity; these people are understood as rational, sociable agents who have a certain moral obligation towards each other (p. 3). In this modern imaginary, humans are capable of shaping, and thus changing, a social order which appears as having a real, factual existence (p. 11). Further elements of this imaginary include the presumption of equality of humans, value of security as common good, division between private and public space and value of reason and individuality. This modern Western social imaginary manifests in social forms such as the market economy or the state.

Taylor sketches the historical conditions and developments of modernity without aiming at causal explanation of the rise of modern social imaginary (p. 8). He moves between the present day and the early modern times as he discusses the consolidation of the new moral order characterising Western modernity. Occasionally, he draws a comparison with the ancient times to highlight the distinguishing features of Western modernity. In asking how come that we are as we are, we do what we do and we think what we think, Taylor points towards several transformations, but he refrains from assigning power to shape social imaginary to any single (nor to several) external factor such as the extension of the markets. Instead, he argues that the unintended and endogenous processes - sets of practices, improvisations-gradually change the meaning people assign to them (p. 30). As Hernando (2017) demonstrates, some aspects of modernity have deeper roots than Taylor's work might suggest. In particular, individuated identity that has developed since the prehistorical times and which is absent in 
the social order of the present-day egalitarian societies ${ }^{1}$ made the Western modern moral order possible to emerge.

Hernando (2017) argues that with growing mobility and specialisation of tasks performed to secure survival, humans-primarily men, at first - gradually developed a new type of largely unconscious self-perception (identity) which was based on their belief of own difference from the group they were born into and on the fantasy of own superiority and control vis-àvis nature (p. 107). She argues that this process was conditioned by the technological advancement which enabled humans to feel in control, and thus safe, in the world (Elias 1991, 1994). Rationality and change are central to this feeling. Both seem to us now natural and universal to the extent that capability of rational thinking and (personal and societal) change as something factual and desirable are considered as intrinsic essence of humanity, despite that they are time and space specific, hence exceptional (Hernando 2017: 60, 63). Rationality has become the main pillar on which Enlightenment thought rests (Honneth 1987; Beiser 1996; Dupré 2004), but Hernando argues that the belief in reason and its power can be traced back to the prehistoric humans and investigated by studying their material culture. Contrary to these authors who associate change as exclusively modern feature (Wagner 2012; Fukuyama 1992; Mouzakitis 2017), she claims that change that humans dare, desire and value as a mode of survival is much older than the modern idea of progress and acceleration (Hernando 2017: $45,134)$. Both rationality and change are powerful elements in telling the story of humanity in terms of becoming (better) then we were, embracing risks and imagining the future. It has led to development of (positivist) science and the claim of primacy of scientific expertise. It also ensued in a particular understanding of the world which relies on our reducing of its complexity with the help of simple dichotomies, such as nature-culture, reason-emotion or individual-society (Hernando 2017: 3-4). ${ }^{2}$

The main argument that Hernando develops is that this rational, individuated human ( $\operatorname{man}$ ) can maintain the imaginary of the world and himself only by denying the importance, in fact the necessity, of strong emotional bonds with his or her own group and the indispensability of human interrelatedness and interdependence. Yet to sustain the image of oneself as an individual defined by his or her personal difference from another human (along the lines of gender, skin colour, hair texture, ethnicity, religion, lifestyle, taste, body size, education, class, income, etc.) is possible only if the deepest emotional existential need of humans is fulfilled despite that it is denied. Thus, the myth of individuality requires a complex system of 
substitution and delegation, and Hernando claims that gender inequality regime is such a mechanism that enables (wo)men to sustain the fantasy of an autonomous and rational individual. ${ }^{3}$ Within this regime, women have been in charge of forging bonds, while men have substituted the bonds that had once linked them to their original group for alliances with peers inside and outside their own groups (Hernando 2017). Gender hierarchy is central to this type of emotional relationships maintained by individuated men (Connell and Messerschmidt 2005). Yet Hernando (2017: 111) argues that the fantasy of individuality has long stopped being an exclusive feature of men, and she stresses that both men and women are to various degrees individuated. The coexistence of two modes of identity produces a contradiction, a tension which cannot be escaped easily, and which often disembogues into nostalgia for community and conviviality.

Without judging the historical truth or the correctness of Hernando's or Taylor's arguments, I will apply them as heuristic to engage with the literature on conviviality. I take into account that this approach is necessarily selective and reductionist, but I believe it helps to focus these elements of the conviviality debate which often remain obvious and thus hidden. Also, it opens up a possibility to think of conviviality as an alternative to the current mode of being in the world.

\section{Re-Reading the Convivial Fantasy with Heuristic of (Western Modern) Social IMAginary}

\section{Conviviality as Courtesy}

In its everyday meaning, conviviality is related to joyful gatherings, good company and feasting (Dunlap 2009; Freitag 2014; Phull et al. 2015). The growing scholarly interest in meetings involving eating, drinking and conversing seems paradigmatic to the current concern with less formal (comparing to, e.g., community) configurations (Harris 2016). Several themes tend to repeat in the debate. First, various scholars attend to the everyday 'gestures of conviviality' in ephemeral situations in urban spaces. Such gestures express a set of rules that prohibit aggressive or disrespectful conduct and prescribe friendly communication in situations which may not necessarily invite such behaviour (Goffman 1963, 1971; Laurier and Philo 2006; Wise and Velayutham 2014; Georgiou 2017). Second, much scholarly attention is dedicated to a particular social setting in urban spaces saturated by immigrants and by diversity of their languages, practices, products and signage (Amin 2002; Gilroy 2006; Amin 2012b; Noble 2013; 
Wessendorf 2014; Wise and Velayutham 2014; Padilla et al. 2015; Wise 2016). In this context, conviviality appears in result of a certain competence people have to navigate this diversity, facilitated by a particular material infrastructure which slows traffic and invites dwelling. Confusingly, this competence was previously labelled intercultural, later cosmopolitan, and now it appears as a basic human feature. Not only is this shift a cause of confusion, for the difference between intercultural, cosmopolitan and convivial is fuzzy; by shifting the focus from cosmopolitan to convivial, it is suggested that the competence to successfully operate in such urban spaces is ordinary and universal.

The heuristic of modern social imaginary helps to address two issues troubling these debates. First, we may argue that the debate of conviviality reveals little new; at least, it misses to declare what is new about such convivial situations it describes. Long before the interest in conviviality, social historians pointed to the fact that all kinds of encounters-from ceremonial and formal to the ephemeral ones in street or coffee houses - are shaped by rituals and conventions (Withington 2007). What now is termed 'gestures of conviviality' is a form of courtesy. Courtesy is a way of acting as though one would be in personal relations with others who are not ones kin. Since Renaissance, courtesy has been the core element of the modern cultural competence (O'Callaghan 2004; Abrams and Ewan 2017). The same kind of skills that enabled people in the early modern Europe to socialise in public across gender and socio-economic status (Curtin 1985; Withington 2007), without questioning it or aiming at its destabilisation-speaking properly (and in foreign language), being friendly, showing respect, displaying tolerance towards other religious beliefs, knowledge of other places and cultures or easiness with and preference for foreign tastes and foods-is now considered central to operate in settings differentiated along the lines of ethnicity, race or religion. But we know that courtesy has been an outcome of (elitist) humanistic education that was not available to all (Taylor 2004). For example, women in Europe (with few exceptions) were long excluded from university studies and were educated for silence rather than for conversation (Gibson 1989). Such 'thin conviviality' indeed operates hand in hand with sexism or racism. By assuming that convivial encounters are a natural instinct of individuals as social beings, and courtesy is a skill we all carry in us to handle such encounters, the scholarship misrecognises the variety of forms of conviviality (Heil 2013).

Sketching the long and complex transformation into modernity, Taylor points to the role of courtesy in development of a new paradigm of sociability (Taylor 2004). In this respect, he follows Norbert Elias who 
argued the growing importance of conversation and politeness for the civilising process as a mean of regulating living together in the increasingly urbanised world (Elias 1994). Courtesy thus carries a second meaning, as mode of governing of social relations. To look at situations which are now termed 'convivial' through the lens of courtesy helps thus to address a second trouble of the conviviality debate, which is the function of courtesy (and possibly conviviality) for maintaining a particular social order. It is because courtesy in encounters - conversation, talking, pleasing, being tolerant and open - creates a situation of 'quasi-equality' which Taylor (2004) considers characteristic of Western modernity. The systematic treatment of 'others' as if they were equals belonged to the cultural capacity of European elites in the Enlightenment and beyond this period (Gordon 1994; Bryson 1998; Klein 2012). Georg Simmel also attended to how enjoyable gatherings promising egalitarian order are foundational of modern sociability (Simmel and Hughes 1949).

The lens of courtesy brings thus another aspect to light which has so far been largely neglected: the centrality of the normative of equality and how it operates in daily encounters in modern urban spaces to create a set of expectations towards people in such spaces. The (modern) ideal of equality motivates people to suppress the difference (e.g. age, gender, class, religion or ethnicity) and the system which relies on it (Gilroy 2004) and to rest the interaction of the agreement on the commonality (such as friendship, shared interest, ideological conviction, common goals).

Yet bridging differences by mean of courtesy between interacting individuals should not be mistaken for overcoming these differences. Gatherings labelled 'convivial' often remain highly exclusive along the lines of friendship, kin, gender, class or ethnicity and race (Nayak 2017). This kind of simultaneity of conviviality and exclusion due to pertaining hierarchies of power is often addressed as a paradox (Back 2016; Nayak 2017; Tyler 2017; Neal et al. 2018). But if we return to the notion of courtesy, we gain a slightly different angle to look at this coexistence. As Simmel or Taylor emphasised, convivial situations generate nothing more than a mere impression of freedom from material or other axes of inequality between the participants (Simmel and Hughes 1949).

This promise of freedom from structural inequalities is essential and needs further investigation. Such take on conviviality requires us to reconsider the modern Western claims of recognition of individual difference, for example. We also need to dedicate more attention to the workings of equality claims. Paradoxically, the sort of 'convivial cultural competence' 
resting on the ideal of equality both helps to silence out structural inequalities and produces new lines of exclusion. As Arnold and König (2017) showed for anti-Semitic tendencies in contemporary Berlin, those who do not display convivial conduct in interreligious and interethnic encounters are refused not only having the required cultural competence but more generally civility.

\section{Conviviality as Civility}

Civility in Western modernity stands continuedly for a skill that enables cohabitation without rancour, a rational behaviour that requires to abstain from the excesses of antagonism despite differences (Bailey 1996). It is rooted in courtesy, but in the course of the reinforcement of modernity, it starts to denote a mode of governing societies, not only interactions (Bryson 1998). 'Being civil' stands thus not only for behaving properly, but means also being a contributing, active, responsible and conscious member of a group. This aspect of civility is central to these works on conviviality which consider conflict as functional to social order. Partly, this body of work resembles the ideas first formulated by Simmel (1903), but the political theories of agonism seem a stronger source of inspiration. These theories claim that conflict is productive to politics if it is framed by rules (Mouffe 2016). If conflict is practised as conversation ("war with words"), it offers a possibility of convivial interaction despite genuinely different and incompatible identities and ideas people have (Amin 2002; Sandercock 2003; Gilroy 2004: 4; Wood and Landry 2008).

The attractiveness of the agonist approach in urban multicultural setting (Coser 1956; Karner and Parker 201 1; Amin 2008, 2012a; Landau 2014; Rishbeth and Rogaly 2018$)^{4}$ lies in how it acknowledges the provisional character of identities (Mouffe 2000). This understanding seems to fit the trend in migration and diversity studies to de-centralise and de-stabilise the categories of identities and to demonstrate their hybrid and fluid nature (Bhabha 1994; Hall 1992; Kasinitz et al. 2004; Bradatan et al. 2010). At the same time, political agonism recognises the human need for belonging to a certain social group (Mouffe 2005). Accordingly, urban multicultural spaces can become place for productive engagement with difference if participants adhere to the ethics of agonistic respect and understand ethnic, religious or racial differences as negotiable identifications. Agonism in urban settings can thus enable resolving tensions to produce fresh syntheses and thus result in conviviality (Amin 2002, 2008; Hinchliffe and 
Whatmore 2006). Such convivial condition in turn embraces conflict and counters communitarianism which values harmony based on homogeneity (van Leeuwen 2014).

This understanding of conviviality requires a particular kind of public space which is imagined as free from private and economic interests (Peattie 1998; Banerjee 2001) and state influence; instead, it offers the possibility for people to connect to each other through multiple relationships, to access resources and practise empathy (Boyd 2006; Nyamnjoh 2002). Such public space is thus a location of democratic rule and enacting citizenship which goes beyond claiming rights vis-à-vis the state (Robins et al. 2008; Nyamnjoh 2002). Typically, parks (Neal et al. 2015) and communal gardens (Shepard 2009; Aptekar 2015) were investigated so far as places in which people probe a convivial mode of togetherness. Unlike classical civil engagements, convivial civil togetherness is also concerned with the future of humanity as the whole and thus with the condition of the natural environment. Often such (urban) spaces become laboratories for de-growth and green economies and sustainable living in general (Cato 2009; Milbourne 2012).

The everyday civic mode of being in the city can be understood as an element of an emerging community beyond political authority, a bottomup movement that aims at a new mode of cohabitation on Earth based on human solidarity, also across generations. This aspect is present in Lourdes Arizpe's proposal for conviviability-compatible living together (Arizpe 1998, 2015; Arizpe et al. 2016). Arizpe stresses the centrality of the principle of non-exploitation and cooperation; only if this principle is realised, humans could eliminate problems of poverty, inequality, political persecution and conflict, social exclusion and cultural repression. Arizpe's vision requires more than shifting power to civil society; it also necessitates that this empowered civil society includes groups so far marginalised: minorities, ethnic groups and women.

The recent Convivialist Manifesto (Caillé 2014) makes a similar proposal, inspired by de-growth and other social movements (Adloff 2014). It is critical of how humans subordinated planetary future to the principle of abstract growth. 'Our society' is presented in the text as enslaved by economic measures and consumption. The renewal towards conviviality is the bottom-up task of a civil society, for the politics has proved to be incapable of governing in a sustainable and just manner. The authors of the Manifesto acknowledge the important role of organisations and groups from civil society that so far worked for more justice, women's and minorities' 
rights, fair trade and sharing economy. And it calls for more solidarity and joint actions among these groups, for a quest for convivialism ${ }^{5}$ as common guiding principle (Caillé 2014).

Now, let me give a closer look at these two proposals and how they pursue a vision of new, convivial society which is yet restrained within an old idea of liberal civility (Walzer 2002).

\section{Conviviality as Collaboration}

The group of Convivialists around Alain Caillé and Lourdes Arizpe both build their proposal around the civil society. It is a liberal civil society in which individuals collaborate across their groups. The aim of such collaboration is clear: more justice and more sustainability to all. Alternative future scenarios enlisted by the Manifesto are ambitious: victory of democracy, end of colonialism, parity and equality of men and women, eradication of hunger and deprivation and autonomy of practice. While it is clear what needs to be done, the Manifesto is more concerned with how to achieve this alternative future, and the answer that it gives is indeed truly modern: convivial society can be achieved through joint effort (solidarity) and exchange (reciprocity) based on the principle of non-exploitation and preservation which remedy for rivalry and violence between humans.

The Manifesto understands collaboration of individuals as interest-free (in economic terms), as taking and giving that includes natural environment and animals. This strongly resembles Arizpe's ideas around sustainable living and inter-generational solidarity. Arizpe's conviviability requires people to re-define their attitudes towards each other as cultural others to achieve a common goal. While Arizpe postulates that individuals change their mental orientation, the Manifesto wants a throughout re-making of the very principles of social life in the spirit of radical universal equality. But alike Arizpe's older proposal, it pictures an individual as naturally aspiring to have its uniqueness recognised. It points to a tension between individual and community if the individual's desire for recognition is not satisfied (Caillé 2014). Prioritising individual's rights and well-being, it seeks a mode of living together which accommodates diversity of both individuals and groups, as well as rivalry between individuals' desires. Individual and society need to be kept in equilibrium. A 'healthy society' depicted in the Manifesto (ibid.: 24) should prevent violence and assure harmony and cooperation (Honneth 1996). The model for future society adopted in the Manifesto is to be based on care and compassion (Caillé 2014: 29). The community 
is there to serve the individual to develop potentials and capacities. The Manifesto reflects thus the idea of a social order based on autonomy of individuals, which results in their capability for a social contract (Gutmann 2013). The moral obligation is directed from community to the individual: the convivial society is implicated in collaboration of social individuals.

Also, Ivan Illich's much earlier proposal for conviviality relies on the idea of collaborating individuals. To enable such collaboration, people need tools that guarantee their freedom (Illich 1973). In Illich's vision, a convivial society is the one in which ordinary individuals re-gain control over technology to foster sustainable growth and subjective well-being. Illich argues that radical reconfigurations of institutions, in particular the education system, are required to achieve this aim. Illich's convivial society is based on a social economy, on sharing, combining and developing resources and capabilities through new forms of interaction, services and learning methods.

Analysing the work of Illich, Reagan (1980) argued that the collaboration that Illich had in mind is incompatible with the neo-liberal idea of community of autonomous and self-responsible individuals. Instead, the foundations of Illich's proposal for a convivial society are to be found in medieval social thought. The difference is how the relationship between the individual and community is imagined in the liberal social thought that sees the individual freedom in need of protection against the forces of community (Reagan 1980). Illich's imaginary of a community is instead that of an enabling one-an individual gains personal freedom through membership in community. Despite being largely simplistic (Black 1988; Siedentop 2015), Reagan's distinction between the medieval and liberal modern thought is worth attention for it points to the central problem of the conviviality debate: the relationship between individual and community.

Following this trail, we can ask how the relation between individual and community is imagined in these works that focus on fleeting encounters in urban spaces. There is not a single possible answer: some works on conviviality tend to see a community as emerging when individuals choose to collaborate for common good. These are works which focus on semipublic spaces (Peterson 2017), for example co-housing projects (Jarvis 2017). Other works consider the messiness and contextuality of human (and material) encounters, their forms and outcomes (Darling and Wilson 2016). Collaboration - if at all the term is used in this body of work-stands implicitly for an effort of invisible actors who create the infrastructures of 
convivial encounters: urban planners, managers of public facilities, shop assistants, cleaning staff taking care of parks and streets, etc. At the same time, community - even if in itself ephemeral-is nothing pre-given, but instead, it starts when the individuals give a start to it, by their minimal engagement, personal commitment to respecting others and their individuality and engaging for peace and sustainability.

Alternatively, collaboration stands for 'labour' required from all to create a convivial situation (Lapina 2016). Morgan (2009) considers urban fleeting encounters as collaborative activities in which all parties are involved in forms of work. With de Certeau (1984) we could also conceptualise such collaboration as tactics - sizing and using opportunities in encounters, manipulating them and combining elements of culture that are already there in a new way. So is walking in the city, for example tactical: people use shortcuts in spite of a grid of the streets. Tactics as form of everyday resistance can extend to political collaborations of different social groups (Elwood and Mitchell 2013; Mould 2014), sometimes spanning divisions of ethnicity, race, sexuality and religion and giving birth to new collectives. In this sense, their bond is utilitarian, though not necessarily intentional. Often, though, mobilising the marginalised is restricted within the boundaries of an existing group, which makes them no less convivial.

Valentine and Sadgrove (2012) rightly notice that the transformative powers of such fleeting encounters are overestimated, which results in a romantic view of urban public spaces as enabling tolerance and cosmopolitanism. Such celebratory instances of fleeting encounters tend to equalise conviviality to lack of conflicts and tensions. These accounts seem to mistake the mechanism of compassion with others with the scope of this compassion-the definition of boundaries of the relevant 'others' to whom we feel morally obliged, which is not only historically, geographically and culturally specific (Taylor 1989) but also depends on our biographical trajectory, experiences of friendship and suffering, etc. The preoccupation of social sciences with ethnic, racial and religious strangers obscures these aspects of human encounters (Valentine and Sadgrove 2012).

\section{Conviviality Among Social Individuals}

Research dedicated to the contact hypothesis proves that encounters are transformative only under certain conditions (Zhou et al. 2018). Thus, we should consider a social meaning of encounters which enable people to feel as a member of a group (Barth 1969) and develop an identity of 'self' 
which is a social being. Convivial gatherings with friends, eating, drinking, dancing or listening to music reassure our belonging to a particular social group; us sitting on a bench in a park, or strolling along the streets, listening to music, talking with friends-just doing as others do-reassures our identity as sociable selves. There are many ways of performing belonging to a group of peers, for example through similar dressing or consumption (Hernando 2017). A weekly ritual of wearing a fan club's scarf and having a beer while watching a football game is one possible form of performance which gives the pleasure of community (Giulianotti 2005). These are the moments when difference does not produce exclusion, and we can be indeed 'indifferent to difference'. Such moments produce pride, joy and emotional connectivity with temporarily equal strangers (Simmel and Hughes 1949). Hernando (2017) argues that such (symbolic) associations with (unfamiliar) peers substitute relational identity which we marginalised and denied in the course of modernisation. Relational identity relies on the sense of personhood that cannot be imagined outside of relational bonds. Yet instead of imagining the self as non-existent outside of community, an individuated modern person perceives herself or himself as existing in the world. This implies that there is the world, and the others, outside of the 'self' to which the 'self' can have a relationship. Thus, an individuated modern person assigns a great meaning to relationships for they assure her or him of not being alone (Taylor 1995).

Conviviality literature so far focuses almost exclusively relationships between the autonomous and unfamiliar selves. It considers how they are capable of liberating themselves of ties of kin and ethnic group, religious community or racial collective identity and reach beyond them to others in proximity (Wessendorf 2014; Wise and Velayutham 2014) and in distance, being solidary (Gilroy 2004: 90), as though this would be a universal and desired competence. Thereby, this research pushes the participants to reflect upon the nature and reason for their bonds with others and how the encounters with others impact their subjectivity. Werbner (2002) is critical of how, under the postcolonial condition, subjects are compelled to be aware and be concerned about their interdependence and entanglement with significant (cultural) others (see also Du Bois 1903).

The scholarly emphasis on relationships focuses commonalities, it is what makes us work and belong together rather than what separates us, and this implies some sort of non-hierarchical togetherness and sense of equality. But we need to ask: 'equal in what?' (Kelly 2010). In Western modern contexts, the declared and experienced equality is a carefully constructed 
myth, not only in relations with peers, but in intimate relationships as well (Knudson-Martin and Mahoney 2009). As many people continue to embody traditional gender, ethnic and religious identities, struggles for equality take place mostly in discursive field and are limited to the questions of recognition of difference; they are unsuccessful as long as reason and individuality are considered the only paths to empowerment (Hernando 2017). Thus, those in favour of equality are still capable of sustaining unequal relationships (Hernando 2017).

The supposed division between private and public domains facilitates the fantasy of equality. The dichotomy between private and public has been a main concern of feminist scholarship since more than five decades now (Pateman 1983; Siltanen and Stanworth 1984), but it continues to shape politics, the everyday practices and scholarly debates equally (Armstrong and Squires 2002; Woodward 2015). The conviviality literature is no exception in this respect: it prioritises researching relationships in the public sphere and between strangers, leaving the intimate and kin relationships untouched. This interest corresponds to the devaluation of domesticity and home as irrelevant to politics and social life. Conviviality in private seems given, while in public it needs to be achieved. It has to do with visibility and invisibility of inequality and power and current emphasis on visibility and audibility of ethnic and racial otherness. Exemplarily, migrant women engaged in domestic work continue to be exploited around the globe (Triandafyllidou 2013). While 'conviviality' and 'migrant domestic workers' can be found in one book (Liu-Farrer and Yeoh 2018), these terms cannot be found in one chapter. It seems that global cities inspire conviviality, domestic sphere invites conflict. Both are forms of 'contact zones' between family members and familiar strangers, but they enjoy different kind of scholarly attention.

This tendency goes hand in hand with denying the role of affective and emotional bonds (Hernando 2017). Even if some works trace signs of affectivity and emotions in public spaces, they relate affectivity (fear, hate) rather to distance from others than to bonding with others (Georgiou 2017) or as a quality of spaces rather than people (Anderson 2009). But 'affects' remain largely unspecific in alliances between strangers as in Amin's accounts of urban life (Amin 2012b). Despite that the problem of neglecting affects and emotions is not specific to conviviality literature (for the overview of critique of this tendency in human geography, see [Nayak 2017]), the notion of conviviality sadly does not in fact make any difference to the way social relations are narrated. 
Further, conviviality appears as a new label for fleeting encounters in public spaces, as a potential for meaningful and transformative social relationships. Without doubt, these encounters are important for sociality. Yet we ought not to forget that face-to-face interactions, even those most fleeting, are conducted according to conventions, and they are functional. They are personalised - in the sense that they appear to be like between friendsbut they serve impersonal functions, such as maintaining of community (Wrightson 2013).

\section{What We Cannot See and How Could We Be OTHERWISE}

Through the heuristic of (modern Western) social imaginary, the debate on conviviality appears largely as reflecting classical interest and concerns of modernity, including the concern with global environment risks (Beck $2006,2007,2012$ ). It does not surprise that the interest in conviviality intensified now. The accelerated climate change and persistence of violent conflicts around the globe which cause more refugees arriving at the shore of Western countries give a sense of an approaching catastrophe and impotence of an individual vis-à-vis this challenge (Hernando 2017). Similarly, the peak of the post-industrial era and the acceleration of globalisation produced two earlier convivial turns, with key works of Illich (1973) and Arizpe (1998). Conviviality appears thus again in 'time that needs direction' (American Humanist Association 1973).

Focusing the everyday social interactions, the current debate favours urban public and semi-public spaces. It is interested in how people reconcile equality and diversity and establish a friendly environment while assuring the recognition of uniqueness of individuals. A consensual sociality is here contrasted to the oppressive system of racial and gender inequality which operates on the basis of unchosen designations. The debate which operates with the modern liberal civil society framework produces evidence on conviviality as courtesy and as civility.

If the debate would restrain itself to describing people, places or situations as convivial, we could or indeed should be critical of how such exercise might be dull and unproductive. Instead, the notion of conviviality increasingly aspires to be an analytical tool, a new lens to study the social and a new mode of explanation. I think it cannot fulfil this aspiration as long as it is not explicit about its own underpinnings and thus its own contextuality. Without it, conviviality might be just another (temporary) label for 
situations which have been common anywhere and everywhere. Instead of being productive in understanding such contexts, it might rather reproduce a Western modern model of masculine sociality. By idealising equality and recognition of individual differences, it might obscure injustice and inequality. By idealising the bridging of ethnic difference, it might silent out the emotional bonds which happen within and beyond the kind and which are the very tissue of sociality. By focusing on multicultural urban settings, it might miss to understand sociality beyond intercultural relations and reproduce the difference it wants to tackle. By focusing on courtesy, such conviviality may neglect emotional distance in daily encounters. By stressing civil society, it might obscure the workings of the state as a moral instance which produces selves as belonging to fixed categories. By understanding individuals as 'free choosers' obliged to reciprocity, it is in danger of ignoring the deeper sense of interdependence. By focusing on voluntary encounters, it might reproduce the dichotomy of kin and friendship.

These are multiple dangers to conviviality which the debate should take seriously if conviviality is not to share the fate of cosmopolitanism as a 'blown up notion' (Braidotti 2013). What is indeed needed is a dose of 'epistemic disobedience' (Mignolo 2009). The start for it is, as mentioned above, the transparency about the own roots of the interests driving the conviviality debate. The works of Taylor (2004) or Hernando (2017) could be useful, though there are multiple ways to achieving the same aim. We might not be able to fully reject the social imaginary we are part of, but we can at least assure we are aware of some of the fantasies it includes. We might then try to 'be otherwise'. ${ }^{6}$ For me, it means to ask an alternative question as soon as one question is asked. It means destabilising the perspective already taken. Exemplarily, if conviviality focuses civil society, then why not bringing the state into the debate? In many ways, civil society is not external to state power (Corrigan 1981; Walzer 2002). Ignoring the state, we don't see how it produces certain kinds of social identities (foreigner or national, young or old aged, able or disabled, male or female, adult or child, kin or unrelated). Following this trail, we may think of conviviality through the lens of moral regulation and thus address how things which now appear to us as inevitable and natural have become such (Dean 1994; Ruonavaara 1997). But moral regulations are imposed by actors other than the state as well, and so we might ask, for example, how social science makes us see intercultural contact and competence to converse in foreign languages (more or less fluently) more central to sociality than public expression of 
emotions. To be effective, conviviality needs thus to engage with a sense of the contingency of what appears inevitable.

Second, the debate should look closer at why convivial situations are so precious to us (as ordinary people and as scholars). Probably, we all value such moments for they enable identity to be derived directly from the action being shared. Possibly, many contemporary situations are alike litanies or alternate chanting experiences earlier or in other societies (Taylor 1995). To address this aspect would probably bring us to focusing less on epistemological aspects (describing what people think about themselves and the world around) but more on the phenomenology of being the world. In turn, we would not come around putting emotions and affects in the centre of our scholarly interest. So far, the study of non-Western modern societies provide examples of how collective life is inseparable from all forms of intimate relations and affectivity (Overing and Passes 2000; Whittle 2005; Harris, O. J. T. 2011). These works remind us of an alternative to the take on conviviality which considers social relations separately in public and private domain, or these works which imagine humans and their environment as divided (Given 2018).

Third, if conviviality dares to revise the fantasy of equality, it might be able to embrace inequalities and think of an order which is less exclusive and less oppressive than the one we experience now. The studies in egalitarian societies in Amazonia, for example, could be an incentive to formulate how to achieve complementarity beyond hierarchical relations and value others for what they do and not who they are. Here, interdependence and other-dependence might appear a false dichotomy. Conviviality might help to transform the value of interdependence towards interrelatedness which is beyond the choice of individuals (Boisvert 2010). Such 'convivialist epistemology' based on the irreducible sense of with-ness of existence (Boisvert 2010) would be an alternative to a modern relational view on human-human and human-nature encounters.

Finally, being otherwise, conviviality would also need to abandon its utilitarian approach which relies on the sense of human capacity for achieving change. Moreover, it would require to re-define the value of change or even to draw satisfaction from lack of change. For as long as the conviviality debate has certain ends in view-for example security as mutual benefit of collaboration of individuals or reduction of violence in result of daily encounters across ethnic difference-it resembles communitarianism and misses a significant contribution to re-thinking the social. 


\section{Notes}

1. These are past and present-day hunter-gatherer societies which have no chief or specialists of any kind; they rely on oral communication and personal relationships to transmit knowledge and have not developed formal logic or the abstract classifications (Hernando 2017; Fried 1976; Flanagan 1989; Ong 2012).

2. Descola (2013) describes this system of knowledge as 'naturalism' and points to alternative systems which could co-exist with it.

3. In this point, Hernando disagrees with Taylor who considers individualism as a modern phenomenon at expense of community (Taylor 2004); for Hernando, individuality happens at expense of gender equality, not community.

4. Thereby, agonist approaches are also present in urban design and urban planning in works that do not link to the conviviality debate (Munthe-Kaas 2015). Some of these works refer to agonism after Laclau instead of Mouffe.

5. The term 'convivialism' is used by Raymond Boisvert (2010) and the authors of the Manifesto (2014); recently, it gains popularity in context Internet blogs on green living and de-growth initiatives, in particular in France and Germany.

6. I borrow this expression from David Francis, see http://www.carmah.berlin/ reflections/auto-draft-12/, accessed on 8 July 2018.

\section{REFERENCES}

Abrams, Lynn, and Elizabeth Ewan, eds. 2017. Nine Centuries of Man: Manhood and Masculinities in Scottish History. Edinburgh: Edinburgh University Press.

Adloff, Frank. 2014. “'Wrong Life Can Be Lived Rightly': Convivialism-Background to a Debate." In Convivialist Manifesto: A Declaration of Interdependence, edited by Alain Caillé, 5-16. Global Dialogues 3. Duisburg: Käte Hamburger Kolleg.

American Humanist Association. 1973. "Humanist Manifesto II." https:// americanhumanist.org/what-is-humanism/manifesto2/.

Amin, Ash. 2002. "Ethnicity and the Multicultural City: Living with Diversity." Environ Plan A 34 (6): 959-980. https://doi.org/10.1068/a3537.

Amin, Ash. 2008. "Collective Culture and Urban Public Space." City 12 (1): 5-24. https://doi.org/10.1080/13604810801933495.

Amin, Ash. 2012a. Land of Strangers. Cambridge: Polity Press. http://site.ebrary. $\mathrm{com} /$ lib/alltitles/docDetail.action?docID=10691454.

Amin, Ash. 2012b. Land of Strangers 1., Auflage. New York, NY: Wiley.

Anderson, Ben. 2009. "Affective Atmospheres." Emotion, Space and Society 2 (2): 77-81. https://doi.org/10.1016/j.emospa.2009.08.005. 
Aptekar, Sofya. 2015. "Visions of Public Space: Reproducing and Resisting Social Hierarchies in a Community Garden." Sociol Forum 30 (1): 209-227. https:// doi.org/10.1111/socf.12152.

Arizpe, Lourdes. 1998. "Conviviability: The Role of Civil Society in Development." In Civil Society and International Development, edited by Amanda Bernard, 2124. Development Centre studies. Paris: OECD, Development Centre.

Arizpe, Lourdes. 2015. "Convivencia: The Goal of Conviviability." In Culture, Diversity and Heritage: Major Studies, vol. 12, edited by Lourdes Arizpe, 165167. SpringerBriefs on Pioneers in Science and Practice 12. Cham: s.l. Springer International Publishing.

Arizpe, Lourdes, Martin Price, and Robert Worcester. 2016. “The First Decade of Initiatives for Research on the Human Dimensions of Global (Environmental) Change." In Handbook on Sustainability Transition and Sustainable Peace, edited by Hans G. Brauch, Úrsula Oswald Spring, John Grin, and Jürgen Scheffran, 349-359. Hexagon Series on Human and Environmental Security and Peace 10. Cham: s.l. Springer International Publishing.

Armstrong, Chris, and Judith Squires. 2002. "Beyond the Public/Private Dichotomy: Relational Space and Sexual Inequalities." Contemporary Political Theory 1 (3): 261-283. https://doi.org/10.1057/palgrave.cpt.9300059.

Arnold, Sina N., and Jana König. 2017. "Antisemitismus im Kontext von Willkommens- und Ablehnungskultur: Einstellungen Geflüchteter zu Juden, Israel und dem Holocaust." Jahrbuch für Antisemitismusforschung 26 (2017): 303-326.

Back, Les. 2016. Metropolitan Paradoxes: Then and Now. https:// newurbanmulticultures.wordpress.com/2016/05/16/metropolitanparadoxes-then-and-now/.

Bailey, Frederick G. 1996. The Civility of Indifference: On Domesticating Ethnicity. Ithaca: Cornell University Press.

Banerjee, Tridib. 2001. "The Future of Public Space: Beyond Invented Streets and Reinvented Places." Journal of the American Planning Association 67 (1): 9-24. https://doi.org/10.1080/01944360108976352.

Barth, Fredrik. 1969. Ethnic Groups and Boundaries: The Social Organization of Culture Difference. Oslo: Universitetsforlaget.

Beck, Ulrich. 2006. "Living in the World Risk Society." Economy and Society 35 (3): 329-345. https://doi.org/10.1080/03085140600844902.

Beck, Ulrich. 2007. World Risk Society. Reprinted. Cambridge: Polity Press.

Beck, Ulrich. 2012. "Global Risk Society." In The Wiley-Blackwell Encyclopedia of Globalization, edited by George Ritzer, 273. Wiley-Blackwell Encyclopedias in Social Science. Hoboken, NJ: Wiley.

Beiser, Frederick C. 1996. The Sovereignty of Reason: The Defense of Rationality in The Early English Enlightenment. Princeton, NJ: Princeton University Press.

Bhabha, Homi K. 1994. The Location of Culture. London: Routledge. 
Black, Antony. 1988. "The Individual and Society." In The Cambridge History of Medieval Political Thought c.350-c.1450, edited by J. H. Burns, 588-606. The Cambridge History of Political Thought. Cambridge: Cambridge University Press.

Boisvert, Raymond. 2010. “Convivialism: A Philosophical Manifesto." The Pluralist 5 (2): 57-68.

Boyd, Richard. 2006. "The Value of Civility?" Urban Studies 43 (5-6): 863-878. https://doi.org/10.1080/00420980600676105.

Bradatan, Cristina, Adrian Popan, and Rachel Melton. 2010. "Transnationality as a Fluid Social Identity." Social Identities 16 (2): 169-178. https://doi.org/10. $1080 / 13504631003688856$.

Braidotti, Rosi. 2013. "Becoming-World." In After Cosmopolitanism, ed. Rosi Braidotti, Patrick Hanafin, and Bolette Blaagaard, 8-28. Abingdon and New York: Routledge.

Braidotti, Rosi, Patrick Hanafin, and Bolette Blaagaard, eds. 2013. After Cosmopolitanism. Abingdon: Routledge.

Bryson, Anna. 1998. From Courtesy to Civility: Changing Codes of Conduct in Early Modern England. Oxford Studies in Social History. Oxford: Clarendon Press.

Caillé, Alain, ed. 2014. Convivialist Manifesto: A Declaration of Interdependence. Global Dialogues 3. Duisburg: Käte Hamburger Kolleg.

Cato, Molly S. 2009. Green Economics: An Introduction to Theory, Policy and Practice. Reprinted. London: Earthscan.

Connell, R. W., and James W. Messerschmidt. 2005. "Hegemonic Masculinity." Gender \& Society 19 (6): 829-859. https://doi.org/10.1177/ 0891243205278639.

Corrigan, Philip. 1981. “On Moral Regulation: Some Preliminary Remarks." The Sociological Review 29 (2): 313-337. https://doi.org/10.1111/j.1467-954x. 1981.tb00176.x.

Coser, Lewis A. 1956. The Functions of Social Conflict. London: Routledge \& Kegan Paul.

Curtin, Michael. 1985. "A Question of Manners: Status and Gender in Etiquette and Courtesy." The Journal of Modern History 57 (3): 396-423. https://doi. org/10.1086/242859.

Darling, Jonathan, and Helen F. Wilson, eds. 2016. Encountering the City: Urban Encounters from Accra to New York. London and New York: Routledge.

de Certeau, Michel. 1984. The Practice of Everyday Life, trans. Steven Rendall. Berkeley: University of California Press.

Dean, Mitchell. 1994. "“A Social Structure of Many Souls': Moral Regulation, Government, and Self-Formation." Canadian Journal of Sociology / Cabiers canadiens de sociologie 19 (2): 145. https://doi.org/10.2307/3341342.

Descola, Philippe. 2013. Beyond Nature and Culture. Chicago: The University of Chicago Press. 
Du Bois, William E. B. 1903. The Souls of Black Folk: Essays and Sketches. Chicago: Mc Clurg.

Dunlap, Rudy. 2009. "Taking Aunt Kathy to Dinner: Family Dinner as a Focal Practice." Leisure Sciences 31 (5): 417-433. https://doi.org/10.1080/ 01490400902988325.

Dupré, Louis. 2004. The Enlightenment and the Intellectual Foundations of Modern Culture. New Haven and London: Yale University Press.

Elias, Norbert. 1991. The Society of Individuals. Oxford and Cambridge, MA: Blackwell.

Elias, Norbert. 1994. The Civilizing Process: The History of Manners and State Formation and Civilization. Oxford, UK and Cambridge, USA: Blackwell.

Elwood, Sarah, and Katharyne Mitchell. 2013. "Another Politics Is Possible: Neogeographies, Visual Spatial Tactics, and Political Formation." Cartographica: The International Journal for Geographic Information and Geovisualization 48 (4): 275-292. https://doi.org/10.3138/carto.48.4.1729.

Flanagan, J. G. 1989. "Hierarchy in Simple 'Egalitarian' Societies.” Annual Review of Anthropology 18 (1): 245-266. https://doi.org/10.1146/annurev.an.18. 100189.001333 .

Freitag, Ulrike. 2014. “'Cosmopolitanism' and 'Conviviality'? Some Conceptual Considerations Concerning the Late Ottoman Empire." European Journal of Cultural Studies 17 (4): 375-391. https://doi.org/10.1177/ 1367549413510417.

Fried, Morton H. 1976. The Evolution of Political Society: An Essay in Political Anthropology. New York, NY: McGraw-Hill.

Fukuyama, Francis. 1992. The End of History and the Last Man. London: Hamilton.

Georgiou, Myria. 2017. “Conviviality Is Not Enough: A Communication Perspective to the City of Difference." Communication, Culture \& Critique 10 (2): 261-279. https://doi.org/10.1111/cccr.12154.

Gibson, Joan. 1989. "Educating for Silence: Renaissance Women and the Language Arts*." Hypatia 4 (1): 9-27. https://doi.org/10.1111/j.1527-2001. 1989.tb00865.x.

Gilroy, Paul. 2004. Postcolonial Melancholia. Wellek Library Lectures. New York, NY: Columbia University Press.

Gilroy, Paul. 2006. "Multiculture in Times of War." Critical Quarterly 48 (4): $27-45$.

Giulianotti, Richard. 2005. "The Sociability of Sport." International Review for the Sociology of Sport 40 (3): 289-306. https://doi.org/10.1177/ 1012690205060095.

Given, Michael. 2018. "The Precarious Conviviality of Watermills." Archaeological Dialogues 25 (1): 71-94. https://doi.org/10.1017/s1380203818000089.

Goffman, Erving. 1963. Behavior in Public Places: Notes on the Social Organization of Gatherings. London: Free Press. 
Goffman, Erving. 1971. Relations in Public: Microstudies of the Public Order. New York: Basic Books.

Gordon, Daniel. 1994. Citizens Without Sovereignty: Equality and Sociability in French Thought, 1670-1789. Princeton: Princeton University Press.

Gutmann, Thomas. 2013. "Theories of Contract and the Concept of Autonomy." Preprints and Working Papers of the Centre for Advanced Study in Bioethics 55. https://www.uni-muenster.de/imperia/md/content/ $\mathrm{kfg}$-normenbegruendung/intern/publikationen/gutmann/55_gutmann_-_ contract_and_autonomy.pdf.

Hall, Stuart. 1992. “The Question of Cultural Identity." In Modernity and Its Futures, edited by Stuart Hall, David Held, and Tony McGrew, 273-316. Understanding Modern Societies 4. Cambridge: Polity Press.

Harris, Anita. 2016. "Rethinking Youth Conviviality: The Possibilities of Intercultural Friendship Beyond Contact and Encounter." Journal of Intercultural Studies 37 (5): 501-516. https://doi.org/10.1080/07256868.2016.1211627.

Harris, O. J. T. 2011. "Constituting Childhood. Identity, Conviviality and Community at Windmill Hill." In (Re)thinking the Little Ancestor: New Perspectives on the Archaeology of Infancy and Childhood, edited by Mike Lally, 122-132. BAR International Series 2271. Oxford: Archaeopress.

Heil, Tilmann. 2013. "Are Neighbours Alike? Practices of Conviviality in Catalonia and Casamance." European Journal of Cultural Studies 17 (4): 452-470. https://doi.org/10.1177/1367549413510420.

Hernando, Almudena. 2017. The Fantasy of Individuality: On the Sociobistorical Construction of the Modern Subject. Cham: Springer International Publishing. http://dx.doi.org/10.1007/978-3-319-60720-7.

Hinchliffe, Steve, and Sarah Whatmore. 2006. "Living Cities: Towards a Politics of Conviviality." Science as Culture 15 (2): 123-138. https://doi.org/10.1080/ 09505430600707988.

Honneth, Axel. 1987. "Enlightenment and Rationality." The Journal of Philosophy 84 (11): 692-699.

Honneth, Axel. 1996. The Struggle for Recognition: The Moral Grammar of Social Conflicts, lst MIT Press ed., Studies in Contemporary German Social Thought. Cambridge, MA: MIT Press.

Illich, Ivan. 1973. Tools for Conviviality 1. Perennial Library ed. Perennial Library 308. New York, NY: Harper \& Row.

Jarvis, Helen. 2017. "Sharing, Togetherness and Intentional Degrowth." Progress in Human Geography, 0309132517746519. https://doi.org/10. $1177 / 0309132517746519$.

Karner, Christian, and David Parker. 2011. "Conviviality and Conflict: Pluralism, Resilience and Hope in Inner-City Birmingham." Journal of Ethnic and Migration Studies 37 (3): 355-372. https://doi.org/10.1080/1369183x. 2011.526776. 
Kasinitz, Philip, John H. Mollenkopf, and Mary C. Waters. 2004. Becoming New Yorkers: Ethnographies of the New Second Generation. New York, NY: Russell Sage Foundation. http://www.loc.gov/catdir/enhancements/ fyl602/2004046633-b.html.

Kelly, Paul. 2010. "Why Equality? On Justifying Liberal Egalitarianism.” Critical Review of International Social and Political Philosophy 13 (1): 55-70. https:// doi.org/10.1080/13698230903326257.

Klein, Lawrance E. 2012. "Sociability, Politeness, and Aristocratic Self-Formation in the Life and Career of the Second Earl of Shelburne." The Historical Journal 55 (3): 653-677. https://doi.org/10.1017/s0018246x12000088.

Knudson-Martin, Carmen, and Anne R. Mahoney. 2009. "The Myth of Equality." In Couples, Gender, and Power: Creating Change in Intimate Relationships, edited by Anne R. Mahoney and Carmen Knudson-Martin, 43-62. New York: Springer Publishing Company.

Landau, Loren B. 2014. "Conviviality, Rights, and Conflict in Africa's Urban Estuaries." Politics \& Society 42 (3): 359-380. https://doi.org/10.1177/ 0032329214543258.

Lapiņa, Linda. 2016. "Besides Conviviality." Nordic Journal of Migration Research 6 (1). https://doi.org/10.1515/njmr-2016-0002.

Laurier, E., and C. Philo. 2006. "Cold Shoulders and Napkins Handed: Gestures of Responsibility." Transactions of the Institute of British Geographers 31: 193-207. Lisiak, Agata, and Magdalena Nowicka. 2017. "Tacit Differences, Ethnicity and Neoliberalism: Polish Migrant Mothers in German Cities." Gender, Place \& Culture 5 (3): 1-17. https://doi.org/10.1080/0966369x.2017.1334631.

Liu-Farrer, Gracia, and Brenda S. A. Yeoh. 2018. Routledge Handbook of Asian Migrations, lst ed. Florence: Taylor \& Francis. https://ebookcentral.proquest. com/lib/gbv/detail.action?docID=5211381.

Mignolo, Walter D. 2009. "Epistemic Disobedience, Independent Thought and Decolonial Freedom." Theory, Culture \& Society 26 (7-8): 159-181. https:// doi.org/10.1177/0263276409349275.

Milbourne, Paul. 2012. "Everyday (In)justices and Ordinary Environmentalisms: Community Gardening in Disadvantaged Urban Neighbourhoods." Local Environment 17 (9): 943-957. https://doi.org/10.1080/13549839.2011. 607158.

Moore, Henrietta. 2013. "The Fantasies of Cosmopolitanism." In After Cosmopolitanism, ed. Rosi Braidotti, Patrick Hanafin, and Bolette Blaagaard, 97-110. New York and London: Routledge.

Morgan, D. H. J. 2009. Acquaintances: The Space Between Intimates and Strangers. Sociology and Social Change. Maidenhead: Open University Press. http://site. ebrary.com/lib/academiccompletetitles/home.action.

Mouffe, Chantal. 2000. The Democratic Paradox. Phronesis. London: Verso. 
Mouffe, Chantal. 2005. On the Political. Thinking in Action. London and New York: Routledge. http://site.ebrary.com/lib/alltitles/docDetail.action? docID $=10462625$.

Mouffe, Chantal. 2016. "Democratic Politics and Conflict: An Agonistic Approach." Politica Común 9 (20180419). https://doi.org/10.3998/pc. 12322227.0009.011.

Mould, Oli. 2014. "Tactical Urbanism: The New Vernacular of the Creative City." Geography Compass 8 (8): 529-539. https://doi.org/10.1111/gec3.12146.

Mouzakitis, Angelos. 2017. "Modernity and the Idea of Progress." Frontiers Sociology 2: 177. https://doi.org/10.3389/fsoc.2017.00003.

Munthe-Kaas, Peter. 2015. "Agonism and Co-Design of Urban Spaces." Urban Research \& Practice 26 (1): 1-20. https://doi.org/10.1080/17535069.2015. 1050207.

Nayak, Anoop. 2017. "Purging the Nation: Race, Conviviality and Embodied Encounters in the Lives of British Bangladeshi Muslim Young Women." Transactions of the Institute of British Geographers 42 (2): 289-302. https://doi.org/ $10.1111 / \operatorname{tran} .12168$.

Neal, Sarah, Katy Bennett, Allan Cochrane, and Giles Mohan. 2018. Lived Experiences of Multiculture: The New Social and Spatial Relations of Diversity. Routledge Research in Race and Ethnicity 23. London: Routledge, Taylor \& Francis Group.

Neal, Sarah, Katy Bennett, Hannah Jones, Allan Cochrane, and Giles Mohan. 2015. "Multiculture and Public Parks: Researching Super-Diversity and Attachment in Public Green Space." Population Space Place 21 (5): 463-475. https://doi. org/10.1002/psp.1910.

Noble, Greg. 2013. "Cosmopolitan Habits: The Capacities and Habitats of Intercultural Conviviality." Body and Society 19 (23): 162-185.

Nowicka, Magdalena, and Steven Vertovec. 2014. "Comparing Convivialities: Dreams and Realities of Living-with-Difference." European Journal of Cultural Studies 17 (4): 341-356. https://doi.org/10.1177/1367549413510414.

Nyamnjoh, Francis. 2002. "'A Child Is One Person's Only in the Womb': Domestication, Agency, and Subjectivity in the Cameroonian Grassfields." In Postcolonial Subjectivities in Africa, edited by Richard P. Werbner. 1. publ. Postcolonial Encounters. London [u.a.]: Zed Books.

O'Callaghan, Michelle. 2004. "Tavern Societies, the Inns of Court, and the Culture of Conviviality in Early Seventeenth-Century London." In A Pleasing Sinne: Drink and Conviviality in Seventeenth-Century England, edited by Adam Smyth, 37-51. Studies in Renaissance Literature 14. Cambridge: Brewer.

Ong, Walter J. 2012. Orality and Literacy: The Technologizing of the Word. With the assistance of J. Hartley, 30th anniversary edition. New Accents. London and New York: Routledge. 
Overing, Joanna, and Alan Passes, eds. 2000. The Anthropology of Love and Anger: The Aesthetics of Conviviality in Native Amazonia. London and New York: Routledge.

Padilla, Beatriz, Joana Azevedo, and Antonia Olmos-Alcaraz. 2015. "Superdiversity and Conviviality: Exploring Frameworks for Doing Ethnography in Southern European Intercultural Cities." Ethnic and Racial Studies 38 (4): 621-635. https://doi.org/10.1080/01419870.2015.980294.

Pateman, Carole. 1983. "Feminist Critiques of the Public/Private Dichotomy." In Public and Private in Social Life, edited by Stanley I. Benn and Gerald F. Gaus, 281-303. London: Croom Helm.

Peattie, Lisa. 1998. "Convivial Cities." In Cities for Citizens: Planning and the Rise of Civil Society in a Global Age, edited by Clyde M. Douglass and John Friedmann, 247-253. Chichester: Wiley.

Peterson, Melike. 2017. "Living with Difference in Hyper-Diverse Areas: How Important Are Encounters in Semi-Public Spaces?" Social \& Cultural Geography 18 (8): 1067-1085. https://doi.org/10.1080/14649365.2016.1210667.

Phull, Surinder, Wendy Wills, and Angela Dickinson. 2015. "Is It a Pleasure to Eat Together? Theoretical Reflections on Conviviality and the Mediterranean Diet." Sociology Compass 9 (11): 977-986. https://doi.org/10.1111/soc4.12307.

Reagan, Timothy. 1980. “The Foundations of Ivan Illich's Social Thought.” Educational Theory 30 (4): 293-306.

Rishbeth, Clare, and Ben Rogaly. 2018. "Sitting Outside: Conviviality, Self-Care and the Design of Benches in Urban Public Space." Transactions of the Institute of British Geographers 43 (2): 284-298. https://doi.org/10.1111/tran.12212.

Robins, Steven, Andrea Cornwall, and Bettina von Lieres. 2008. "Rethinking 'Citizenship' in the Postcolony." Third World Quarterly 29 (6): 1069-1086. https://doi.org/10.1080/01436590802201048.

Ruonavaara, Hannu. 1997. "Moral Regulation: A Reformulation.” Sociological Theory 15 (3): 277-293.

Sandercock, Leonie. 2003. Cosmopolis II: Mongrel Cities of the 21st Century. London: Continuum.

Shepard, Benjamin. 2009. "Community Gardens, Convivial Spaces, and the Seeds of a Radical Democratic Counterpublic." In Democracy, States, and the Struggle for Global Justice, edited by Heather Gautney, 273-296. New York: Routledge.

Siedentop, Larry. 2015. Inventing the Individual: The Origins of Western Liberalism. London: Penguin Books.

Siltanen, Janet, and Michelle Stanworth. 1984. "The Politics of Private Woman and Public Man." Theory and Society 13 (1): 91-118. https://doi.org/10.1007/ bf00159258.

Simmel, Georg. 1903. "Die Grosstädte und das Geistesleben.” In Die Grossstadt. Vorträge und Aufsätze zur Städteausstellung: Jabrbuch der Gehe-Stiftung Dresden, edited by Theodor Petermann, 185-206. Dresden: Zahn \& Jaensch. 
Simmel, Georg, and Everett C. Hughes. 1949. "The Sociology of Sociability." American Journal of Sociology 55 (3): 254-261. https://doi.org/10.1086/ 220534.

Taylor, Charles. 1989. Sources of the Self: The Making of the Modern Identity. Cambridge, MA: Harvard University Press.

Taylor, Charles. 1995. “The Dialogical Self.” In Rethinking Knowledge: Reflections Across the Disciplines, edited by Robert F. Goodman and Walter R. Fisher, 57-67. SUNY Series in the Philosophy of the Social Sciences. Albany: State University of New York Press.

Taylor, Charles. 2004. Modern Social Imaginaries. Durham and London: Duke University Press.

Triandafyllidou, Anna, ed. 2013. Irregular Migrant Domestic Workers in Europe: Who Cares? Farnham, Surrey: Ashgate.

Tyler, Katharine. 2017. "The Suburban Paradox of Conviviality and Racism in Postcolonial Britain." Journal of Ethnic and Migration Studies 43 (11): 18901906. https://doi.org/10.1080/1369183x.2016.1245607.

Valentine, Gill, and Joanna Sadgrove. 2012. "Lived Difference: A Narrative Account of Spatiotemporal Processes of Social Differentiation." Environment and Planning A: Economy and Space 44 (9): 2049-2063. https://doi.org/10. 1068/a44491.

van Leeuwen, Bart. 2014. "Absorbing the Agony of Agonism? The Limits of Cultural Questioning and Alternative Variations of Intercultural Civility." Urban Studies 52 (4): 793-808. https://doi.org/10.1177/0042098014528548.

Wagner, Peter. 2012. Modernity: Understanding the Present. Cambridge: Polity Press.

Walzer, Michael. 2002. "Equality and Civil Society." In Alternative Conceptions of Civil Society, edited by Simone Chambers and Will Kymlicka, 34-49. Princeton, NJ: Princeton University Press.

Werbner, Richard P. 2002. "Postcolonial Subjectivities: The Personal, the Political and the Moral." In Postcolonial Subjectivities in Africa, edited by Richard P. Werbner. 1. publ. Postcolonial Encounters, 1-22. London [u.a.]: Zed Books.

Wessendorf, Susanne. 2014. "'Being Open, but Sometimes Closed'. Conviviality in a Super-Diverse London Neighbourhood." European Journal of Cultural Studies 17 (4): 392-405. https://doi.org/10.1177/1367549413510415.

Whittle, A. 2005. "Lived Experience in the Early Neolithic of the Great Hungarian Plain." In (Un)settling the Neolithic, edited by Douglass W. Bailey, 64-70. Oxford: Oxbow Books.

Wise, Amanda. 2016. "Becoming Cosmopolitan: Encountering Difference in a City of Mobile Labour." Journal of Ethnic and Migration Studies 42 (14): 22892308. https://doi.org/10.1080/1369183x.2016.1205807. 
Wise, Amanda, and Selvaraj Velayutham. 2014. "Conviviality in Everyday Multiculturalism: Some Brief Comparisons Between Singapore and Sydney." European Journal of Cultural Studies 17 (4): 406-430. https://doi.org/10.1177/ 1367549413510419.

Withington, Phil. 2007. "Company and Sociability in Early Modern England." Social History 32 (3): 291-307. https://doi.org/10.1080/ 03071020701425338.

Wood, Phil, and Charles Landry. 2008. The Intercultural City: Planning for Diversity Advantage. Reprinted. London: Earthscan.

Woodward, Kath. 2015. "Public and Private Spaces and Relationships." In The Politics of In/Visibility: Being There, edited by Kath Woodward, 80-95. Genders and Sexualities in the Social Sciences. London: Palgrave Macmillan UK; Imprint; Palgrave Macmillan.

Wrightson, Keith. 2013. English Society 1580-1680, 2nd ed. Hoboken: Taylor \& Francis. http://gbv.eblib.com/patron/FullRecord.aspx?p=1223029.

Zhou, Shelly, Elizabeth Page-Gould, Arthur Aron, Anne Moyer, and Miles Hewstone. 2018. "The Extended Contact Hypothesis: A Meta-Analysis on 20 Years of Research." Personality and Social Psychology Review 20:108886831876264. https://doi.org/10.1177/1088868318762647.

Open Access This chapter is licensed under the terms of the Creative Commons Attribution 4.0 International License (http://creativecommons.org/licenses/by/ 4.0 /), which permits use, sharing, adaptation, distribution and reproduction in any medium or format, as long as you give appropriate credit to the original author(s) and the source, provide a link to the Creative Commons license and indicate if changes were made.

The images or other third party material in this chapter are included in the chapter's Creative Commons license, unless indicated otherwise in a credit line to the material. If material is not included in the chapter's Creative Commons license and your intended use is not permitted by statutory regulation or exceeds the permitted use, you will need to obtain permission directly from the copyright holder.

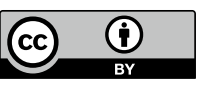

